Images in...

\title{
Calciphylaxis in a paediatric patient
}

\author{
Alison Timmis, ${ }^{1}$ Henry Morgan² \\ ${ }^{1}$ Department of Paediatric Nephrology, Alder Hey Children's NHS Foundation Trust, Liverpool, UK \\ ${ }^{2}$ Department of Paediatric Nephrology, Royal Liverpool Children's Hospital NHS Trust, Liverpool, UK
}

Correspondence to Alison Timmis, atimmis@hotmail.com

\section{DESCRIPTION}

A 17 year old presented with a painful, erythematous lesion to the dorsum of his right foot following minor trauma. The lesion was cold, $5 \mathrm{~cm}$ in diameter with a well-defined edge surrounding scattered petechiae (figure 1). He was unable to move his foot or weight bear due to pain. C-reactive protein and plain $\mathrm{x}$-rays were normal.

The patient has chronic kidney disease (CKD) stage 5 due to IgA nephropathy and had received haemodialysis for 16 months. Serum calcium, phosphate and parathyroid hormone $(\mathrm{PTH})$ were raised at $2.56 \mathrm{mmol} / 1,3.32 \mathrm{mmol} / \mathrm{l}$ and $19.5 \mathrm{pmol} / \mathrm{l}$. Compliance with diet and medication was inconsistent.

A clinical diagnosis of calciphylaxis was made. The patient was treated with daily dialysis sessions, cessation of both vitamin $\mathrm{D}$ analogues and calcium-based phosphate binders and instigation of Cinacalcet. He required opiate analgesia. The lesion improved with control of his calciumphosphate product.

\section{DISCUSSION}

Calciphylaxis is rare in paediatric populations ${ }^{1}$ and can be confused with cellulitis, fracture or soft tissue injury. It is characterised by vascular calcification, thrombosis and skin necrosis. ${ }^{2}$ It is seen in patients with CKD 4-5 as a consequence of raised serum calcium and phosphate concentrations and secondary hyperparathyroidism. ${ }^{2}$ The prognosis is often poor with chronic, non-healing ulcers leading to sepsis and death. ${ }^{2}$ Treatment is with reduction of the calcium-phosphate product, adequate analgesia and aggressive surgical wound care. ${ }^{2}{ }^{3}$ Cinacalcet, a calcimimetic agent, increases the sensitivity of the parathyroid gland to calcium and therefore decreases PTH levels. Case reports of the use of Cinacalcet in calciphylaxis suggest improved wound healing. ${ }^{3}$

\section{Competing interests None.}

Patient consent Obtained.

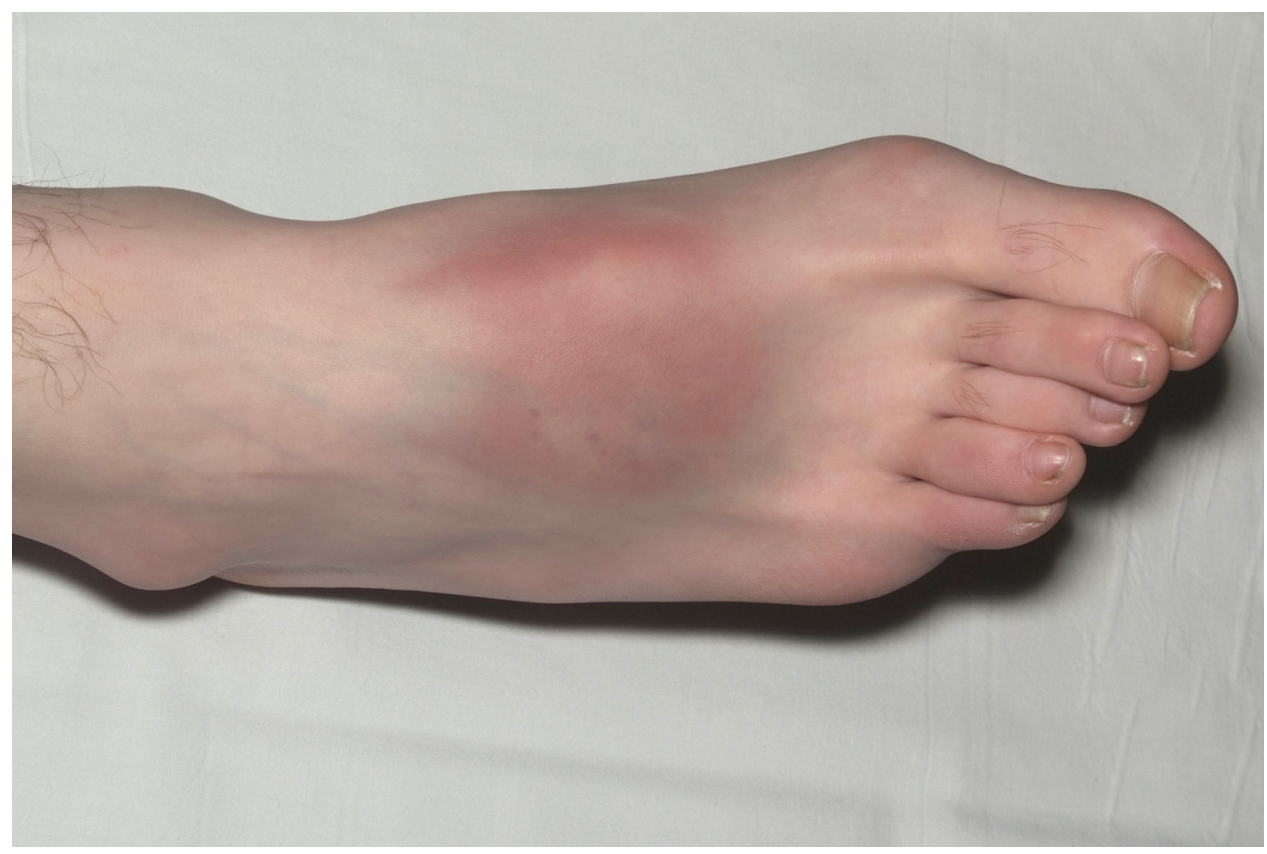

Figure 1 Calciphylaxis of the foot. 


\section{BMJ Case Reports}

\section{REFERENCES}

1. Toprak D, Bircan Z, Gokalp AS. Calciphylaxis in pediatric end-stage renal disease. Ped Nephrol 2005;20:1776-80.

2. Weenig RH, Sewell LD, Davis MD, et al. Calciphylaxis: natural history, risk factor analysis, and outcome. J Am Acad Dermatol 2007;56:569-79.

This pdf has been created automatically from the final edited text and images.

Copyright 2010 BMJ Publishing Group. All rights reserved. For permission to reuse any of this content visit http://group.bmj.com/group/rights-licensing/permissions.

BMJ Case Report Fellows may re-use this article for personal use and teaching without any further permission.

Please cite this article as follows (you will need to access the article online to obtain the date of publication).

Timmis A, Morgan H. Calciphylaxis in a paediatric patient. BMJ Case Reports 2010;10.1136/bcr.05.2010.2989, date of publication

Become a Fellow of BMJ Case Reports today and you can:

Submit as many cases as you like

Enjoy fast sympathetic peer review and rapid publication of accepted articles

Access all the published articles

Re-use any of the published material for personal use and teaching without further permission

For information on Institutional Fellowships contact consortiasales@bmjgroup.com

Visit casereports.bmj.com for more articles like this and to become a Fellow
3. Raymond CB, Wazny LD. Sodium thiosulfate, bisphosphonates, and cinacalcet for treatment of calciphylaxis. Am J Health Syst Pharm 2008;65:1419-29. 